\title{
IN VITRO FERTILIZATION AND DEVELOPMENT OF IN VITRO VERSUS IN VIVO MATURED RABBIT OOCYTES
}

\author{
A.E. Abdel-Khalek ${ }^{1}$, Turk, M. Dora ${ }^{2}$, Sh. M. Shamiah ${ }^{3}$ and I. T. El-Ratel ${ }^{3}$ \\ 1- Animal Production Department, Faculty of Agriculture, Mansoura University, Egypt, 2- Poultry \\ Production Department, Faculty of Agriculture, Mansoura University, Egypt, 3- Animal Production \\ Research Institute, Agricultural Research Center, Giza, Egypt
}

\section{SUMMARY}

This study was carried out to evaluate the effect of adding two types of serum, bovine serum albumin (BSA) and doe rabbit serum (DRS) to maturation tissue culture medium (TCM-199) on the in vitro maturation rate of follicular oocytes of rabbits, and to, evaluate the success rate of in vitro fertilization and development of in vivo versus in vitro mature rabbit oocytes. About 245 immature complete cumulus oocytes were recovered immediately from ovaries of sacrified rabbit does treated with PMSG (75 IU) for 48 h. Maturation medium (TCM-199) supplemented with 10\% DRS, 6\% BSA or without serum (control) were used. In vitro $(n=245)$ and in vivo $(n=264$, collected from oviduct of does sacrified after $12 \mathrm{~h}$ of $0.02 \mathrm{ml}$ GnRH injection) mature oocytes were used for in vitro fertilization and embryo development evaluation. Results revealed that TCM-199 plus DRS increased the percentage of oocytes at MI (25 vs.15\%, P<0.05) and M II (55 vs. 47.5\%, P>0.05) as compared to control TCM, respectively. However, TCM-199 plus BSA had more positive effect on in vitro maturation of oocyte in term of the lowest percentage of oocytes at germinal vesicles and germinal vesicles break down $(0.0$ and $9.4 \%)$ and the highest one $(73 \%, P<0.05)$ at M II. Fertilization rate was higher $(P<0.05)$ for in vivo than in vitro mature oocytes $(86.3 \mathrm{vs} .62 .5 \%)$. Percentage of embryos 4 -cell stage decreased (18.3 vs. 34.7\%, $P<0.05)$ and at morula stage increased $(30.5$ vs. $16 \%, P<0.05)$ for in vivo as compared to in vitro matured oocytes. However, the percentages of embryos at 2-cell and 8 16-cell stages between in vivo and in vitro matured oocytes were not different. The current study obtained an appropriate rate of success for in vitro fertilization (62.5\%) of in vitro mature rabbit oocytes with about $16 \%$ of them were developed to morula stage (transferable embryos) versus $86.3 \%$ of in vivo mature oocytes were fertilized with about $30.5 \%$ of them at morula stage. Based on the foregoing results of this study, addition of $10 \%$ of bovine serum albumin (BSA) to tissue culture medium (TCM-199) had more beneficial effects on in vitro maturation rate of rabbit oocytes than that occurred with $10 \%$ of doe rabbit serum (DRS). In vitro maturation with 10\% BSA showed success with satisfied in vitro fertilization rate and embryos at morula stage, but still to have lower developmental competence to fertilize in vitro than in vivo matured and in vitro fertilized oocytes.

Keywords: Rabbits, oocytes, in vitro, in vivo, maturation, fertilization, embryo development.

\section{INTRODUCTION}

The application of assisted reproductive technologies in rabbits, such as induction of superovulation, in vitro maturation (IVM), in vitro fertilization (IVF) and ET will help increasing the number of offspring produced by genetically superior parents (El-Maghraby 2004). Maturation of mammalian oocytes is defined as the sequence of events occurring from the germinal vesicle stage to completion of the second meiotic division with formation of the second polar body (Blanco et al., 2011). Nuclear maturation is characterized by the oocyte's ability to resume meiotic division up to metaphase II during in vitro maturation. This is the case for the vast majority of in vitro matured oocytes punctured from antral follicles (Watson, 2007). The serum supplementation of the IVM medium is necessary to obtain a higher cleavage rate and development rate to the blastocyst stage of immature bovine oocytes (Sagirkaya et al., 2004).
Serum sources contain amino acids that play an important role as energy sources, osmoregulators, and $\mathrm{pH}$ stabilizers of maturation media (Bavister, 1995). Supplementation of maturation media with fetal bovine serum (Martin-Lunas et al., 1996), calf serum (Crozet et al., 1993), estrous goat serum (EGS) (Tajik and Shams Esfandabadi, 2003), bovine serum albumin (BSA) plus EGS (Rajikin et al., 1994) or BSA (Holm et al., 1999) as protein sources has been found to be beneficial for achieving high in vitro maturation (IVM), fertilization (IVF) and subsequent development (IVD) rates of immature oocytes.

Better cytoplasmic maturation of pig oocytes matured in vivo could explain the higher developmental competence observed by Sirard and Blondin (1996) because under IVF conditions, oocytes matured in vitro display lower penetration and cleavage rates than those matured in vivo (Laurincik et al., 1994). Also, Leibfried-Rytledge (1987) found that morulae 
and blastocysts were obtained only after in vitro fertilization of bovine oocytes matured in vivo. However, oocytes matured and fertilized in vitro failed to develop in vivo to morulae.

The efficiency of the processes of in vitro maturation, fertilization of oocytes and development of embryos is not sufficiently high. The number of pregnancies obtained under the same conditions is smaller when the transferred embryos are produced in vitro than when they are produced in vivo. Despite the efforts to improve bovine in vitro embryo production, its efficiency is still lower, since only 30 to $40 \%$ blastocyst development is obtained from oocytes after in vitro maturation, fertilization and embryo culture (Sirad et al., 2006). In both, in vivo and in vitro conditions, only the fully grown oocytes can resume meiosis and acquire the ability to be fertilized. Meiotic events are sensitive to various perturbations, such as $\mathrm{pH}$; oxidative stress, toxins and in vitro culture conditions may have profound effects on the genetic competence of in vitro-matured oocytes (Carrell et al., 2005).

The aims of the current paper were to study: 1) the effect of the type of serum (BSA and DRS) supplemented to tissue culture medium (TCM-199) on in vitro maturation rate of rabbit oocytes. 2) Comparing the success rate of in vitro fertilization of in vitro mature with in vivo mature rabbit oocytes.

\section{MATERIALS AND METHODS}

This study was carried out at the International Livestock Management Training Center (ILMTC), Sakha, Kafr El-Sheikh Governorate, belonging to the Animal Production Research Institute, Agricultural Research Center, Ministry of Agriculture, Egypt, during the period from September, 2008 to April, 2009. All chemical substances used in this study were purchased from Sigma (Madrid, Spain), unless otherwise indicated.

\section{Animals:}

A total of 20 New Zealand White (NZW) rabbit does (aging $5.5 \pm 0.34 \mathrm{mo}$ and weighing $3.25 \pm 0.28 \mathrm{~kg}$ ) as oocyte donors as well as 5 NZW matured bucks (aging 7.5 $\pm .0 .47 \mathrm{mo}$ and weighing $3.75 \pm 0.31 \mathrm{~kg}$ ) for semen collection was used in this study. All does and bucks were kept under the same conditions of feeding and management in the station, being individually housed in metal cages $(40$ x $50 \mathrm{x}$ $60 \mathrm{~cm}$ ) provided with feeders and water nipple for drinking in each cage. Does and bucks were fed ad libitum on a commercial pelleted concentrate diet.

\section{Collection of immature oocytes:}

Immature oocytes were recovered from rabbit does $(n=12)$ treated with PMSG (75 IU) and $48 \mathrm{~h}$ later, does were sacrified. Immediately after sacrifing, ovaries were removed, washed by warming harvesting medium (Phosphate buffer saline, PBS) supplemented with $100 \mathrm{IU} / \mathrm{ml}$ of sodium penicillin $\mathrm{G}$ and $100 \mu \mathrm{g} / \mathrm{ml}$ of streptomycin (Misr Co. Pharm., Egypt). Oocytes were collected by slicing the ovaries into glass Petri dishes containing $4 \mathrm{ml}$ of harvesting medium. Ovaries were held with forceps and incisions made with scalpel blades along the whole ovarian surface. Each ovary was washed three times with harvesting medium and then oocytes were searched using stereomicroscopy. Only complete cumulus oocytes with $\geq 5$ layers of complete cumulus cells with homogeneous cytoplasm were used in this study.

\section{Oocyte in vitro maturation: \\ Preparation of doe rabbit serum:}

Doe rabbit serum (DRS) was prepared from blood collected from five rabbit does. The collected blood was centrifuged two times at $3000 \mathrm{rpm}$ for 15 minutes and clear serum was aspirated with Pasteur pipette and placed in another $15 \mathrm{ml}$ sterile centrifuge tubes. These tubes were placed into water bath at $56^{\circ} \mathrm{C}$ for 30 minutes, and then left to cool. Thereafter, serum was placed into $1.5 \mathrm{ml}$ eppendorf tubes and frozen until used.

\section{In vitro maturation procedures:}

Tissue culture medium (TCM-199, powder) was dissolved in deionized double distilled water and $50 \mu \mathrm{g} / \mathrm{ml}$ of gentamicin was added to the medium. On the day of maturation, three types of TCM-199 stock were prepared, the $1^{\text {st }}$ TCM-199 was supplemented with $10 \%$ (v./v.) doe rabbit serum (DRS), the $2^{\text {nd }}$ was supplemented with $10 \%$ (w./v.) bovine serum albumin (BSA) and the $3^{\text {rd }}$ type served as a control medium (without serum). In addition to serum supplementation, $20 \mathrm{mmol}$ final concentration of pyruvate, penicillin G (100 $\mathrm{IU} / \mathrm{ml})$ and streptomycin $(100 \mu \mathrm{g} / \mathrm{ml})$ were added to each type of TCM-199.

All media were adjusted at $\mathrm{pH}$ of 7.3-7.4 and $280-300 \mathrm{mOsm} / \mathrm{kg}$, filtrated by $0.22-\mu \mathrm{m}$ millipore filter (milieux $\mathrm{GV}$, millipore, Cooperation Bedford MOA). About $100 \mu \mathrm{l}$ droplets from each prepared medium was placed into a sterile Petri dish $(30 \times 60 \mathrm{~mm})$ and covered by sterile mineral oil. Dishes used in maturation were previously incubated in a $\mathrm{CO}_{2}$ incubator $\left(5 \% \mathrm{CO}_{2}\right)$ at $37.5^{\circ} \mathrm{C}$ and high humidity for one hour at least for equilibration.

For each TCM-199 type, oocytes were washed three times with $\mathrm{PBS}+3 \%$ BSA and then with TCM-199 to remove substances which prevented maturation. Thereafter, oocytes were placed in medium and incubated for $20 \mathrm{~h}$ at $37.5^{\circ} \mathrm{C}, 5 \% \mathrm{CO}_{2}$ and high humidity. 
Fixation, staining and examination of in vitro matured oocytes:

After $24 \mathrm{~h}$ as a maturation period, oocytes were washed using PBS containing $1 \mathrm{mg} / \mathrm{ml}$ hyaluranidase to remove the cumulus cells. Then, oocytes were washed two times in PBS supplemented with 3\% BSA and loaded on clean slides. Slides were placed into fixation solution (3 ethanol: 1 glacial acetic acid) overnight. Thereafter, oocytes were stained with $1 \%$ orcein in $45 \%$ acetic acid, examined for maturation under phase-contrast microscopy and classified into oocytes with disk-like distribution of chromosomes and intact nuclear envelope (germinal vesicle), oocytes with disk-like distribution of chromosomes and broken down nuclear envelope (germinal vesicle breakdown), oocytes at metaphase I (M I), matured oocytes with polar body exhausted in perivitelline space at metaphase II (M II), and vacuolated oocytes with shrunk cytoplasm or condensed chromatin (degenerated oocytes).

\section{Collection of in vivo mature oocytes:}

Mature oocytes were collected from oviducts excised from rabbit does $(\mathrm{n}=8)$ treated with PMSG (75 IU) and $48 \mathrm{~h}$ later with GnRH $(0.02 \mathrm{ml})$, and then sacrified after $12 \mathrm{~h}$. A hypodermic needle (24-gauge) was threaded into the oviduct at the utero-tubal junction and $2.0 \mathrm{ml}$ PBS of medium was forced through the oviduct, washing the ova out of the infundibulum into a collecting falcon tube and then into plastic tissue culture dishes $(60 \times 15$ $\mathrm{mm})$. Only oocytes collected from oviducts at metaphase II stage (M II), mature oocytes with one large group of chromosome forming an equatorial plate and the remaining chromosomes highly condensed, or which had extruded a polar body, were used in this study.

\section{In vitro fertilization:}

Based on the results of in vitro maturation, in vitro oocytes matured with TCM-199 plus $10 \%$ DRS or $10 \%$ BSA and those in vivo matured were used for in vitro fertilization in this study.

\section{Collection, washing and capacitation of rabbit spermatozoa:}

Semen ejaculates were collected from rabbit bucks using artificial vaginas. The collected semen was examined for sperm motility and concentration and only ejaculates with sperm motility higher than $70 \%$ were used in in vitro fertilization. The sperm cells were washed to remove excess seminal plasma by suspending $200 \mu \mathrm{l}$ raw semen in $5 \mathrm{ml}$ of Tyrode's washing medium (Shamiah, 2004) and centrifuged at $1500 \mathrm{rpm}$ for 5 minutes. After washing, semen was diluted with the same medium up to a final concentration of about $50 \times 10^{6}$ sperm $/ \mathrm{ml}$, supplemented with $20 \mu \mathrm{g} / \mathrm{ml}$ heparin and incubated in $\mathrm{CO}_{2}$ incubator at $37.5^{\circ} \mathrm{C}, 5 \% \mathrm{Co}_{2}$ in air and high humidity for 15 minutes.

\section{In vitro fertilization procedures:}

Fertilization droplets were prepared by pipetting $45 \mu \mathrm{l}$ of fertilization medium (Shamiah, 2004) under sterile mineral oil and incubated in a $\mathrm{CO}_{2}$ incubator at $37.5^{\circ} \mathrm{C}, 5 \%$ $\mathrm{Co}_{2}$ in air and high humidity for one hour. About $3 \mu \mathrm{l}$ washing medium was added to each droplet with 7-10 oocytes (in vitro or in vivo matured oocytes), following by adding 2 $\mu \mathrm{l}$ of prepared semen and then incubated together in $\mathrm{CO}_{2}$ incubator at $37.5^{\circ} \mathrm{C}, 5 \% \mathrm{CO}_{2}$ in air and high humidity for $48 \mathrm{~h}$.

\section{Criteria of cleaved oocytes (embryos):}

After fertilization, the oocytes were examined under inverted microscope to determine the cleavage rate including embryos at 2-cell up to morula stage. Cleaved ova were classified into embryos at 2- cell, 4-cell, 8-16cell and morula stages.

\section{Statistical analysis:}

Data were analyzed by analysis of variance (Statistical Analysis System, SAS Institute Inc., North Carolina, USA, 2000). The differences among means were studied using Duncan's Multiple Range Test (Duncan, 1955).

\section{RESULTS AND DISCUSSION}

In vitro maturation of immature oocytes recovered from ovaries:

Results in Table (1) revealed that TCM-199 plus DRS increased percentages of oocyte at M I (25 vs. $15 \%, \mathrm{P}<0.05)$ and $\mathrm{M}$ II (55 vs. $47.5 \%$, $\mathrm{P}>0.05)$ as compared to control TCM, respectively. However, TCM-199 plus BSA had more positive effect on in vitro maturation of oocyte in term of the lowest percentages of oocytes at GV and GVBD (0.0 and 9.4\%) and the highest one $(73 \%, \mathrm{P}<0.05)$ at $\mathrm{M}$ II.

Protein synthesis is essential for GVBD and for the progression of oocytes to metaphase I (Gifford, 1987). Meiotic maturation refers to nuclear advancement from diplotene stage of prophase to metaphase II (Shamiah , 2004).

In this respect, Kubelka et al. (1988) showed that nuclear maturation refers to the progression of the oocyte nucleus from the germinal vesicle to the M-II stage. So, most reports calculated maturation rate on the basis on percentage of oocytes at metaphase II.

In much of the early research on in vitro maturation of rabbit oocytes, serum was utilized as either the sole constituent or a major constituent of the media.

During IVM of rabbit oocytes with control medium, Meshreky (1997) found that 
percentages of rabbit oocytes at M I and M II stages and degenerated oocytes were 63.7 and $6.9 \%$. This maturation rate was similar to that obtained for the control medium in this study $(62.5 \%)$. However, the corresponding percentages were 73.1 and $3.3 \%$ when fetal calf serum (FCS) was added to TCM-199 as compared to 54.4 and $10.4 \%$ with BSA. On the other hand, Shea et al. (1976) showed that the addition of rabbit serum to TCM 199 was more beneficiation to maturation in vitro than the addition of BSA.

The observed increment in maturation rate of rabbit oocytes with DRS and BSA as compared to the control medium (without sera) in this study may be explained because the serum contains many substances, including enzymes, hormones and various other proteins, any of which might enhance rabbit oocytes maturation (Shea et al., 1976). However, the recorded higher maturation rate with BSA than with DRS may be associated with the variability in the ability of commercial BSA to support cell multiplication and hatching rabbit embryos in culture (Kane, 1985). In this respect, some authors noted that TCM-199 medium supplemented with serum from the same species had almost insignificant effect on maturation rate (Fukui et al., 1997 and Shamiah, 2004).

The conflict of the present results with others reported in the literature may be related to several factors. The in vitro maturation of oocytes was dependent on follicle size or adhesion of cumulus cells to the oocytes (Fukunari et al., 1989), oocyte quality and type of tissue culture with or without hormonal addition (Abdoon et al., 2001). The results show that serum supplementation of the IVM medium is necessary to obtain a higher cleavage rate and development rate to the blastocyst stage of immature bovine oocytes (Sagirkaya et al., 2004).

In vitro fertilization rate of in vitro vs. in vivo mature oocytes:

Results presented in Table (2) show that fertilization rate was significantly $(\mathrm{P}<0.05)$ higher for in vivo than in vitro mature oocytes (86.3 vs. 62.5\%). However, the percentage of unfertilized oocytes relative to total recovered oocytes was higher $(37.5 \%)$ for in vivo than in vitro maturation $(13.7 \%)$. In accordance with the present results, Mills et al. (1973) found that cleavage rate for rabbit ova ranged between 49.5 and $73.5 \%$. They concluded that the rate of fertilization depends on the maturity of ova used.

The obtained fertilization rate of in vitro oocytes was higher than that reported by Kusan et al. (1984), who found that $24 \%$ of rabbit oocytes were fertilized by the perivitelline spermatozoa cultured in Brackett's medium and Minhas et al. (1991) showing that when in vitro matured rabbit oocytes were subjected to in vitro fertilization with capacitated spermatozoa in vitro the fertilization rate was $34.2 \%$. Also, Brackett et al. (1982) mentioned that about $55 \%$ of rabbit oocytes from follicles and oviducts were fertilized. Depending on the type of culture medium used, Mills et al. (1973) showed that the cleavage rate was $53 \%$ for follicular ova when the Brackett medium plus $20 \%$ heated rabbit serum was used for fertilization and 47.5 when the defined medium with pyruvate was used. Rao and Bhattacharyya (1987) recorded fertilization rate of $32-40 \%$ for rabbit ova fertilized in vitro with different types of medium.

On the other hand, higher cleavage rate than that reported in this study was obtained when rabbit ova were recovered from ovarian surface, inseminated and fertilized in vitro (71\%, Brackett et al., 1971) or when rabbit ova were fertilized by sperm treated with amylase (72\%, Hall and Brackett 1976). More success was recorded by Brackett and Williams (1965), who reported that $73 \%$ rabbit ova was fertilized in vitro.

\section{Embryo stages of fertilized in vivo vs. in vitro mature oocytes:}

Examination of in vitro fertilization of in vivo and in vitro matured oocytes revealed four stages of cleaved embryos including 2-cell, 4cell, 8 16-cell and morula. All percentages of embryos at each stage were calculated relative to number of cleaved embryos. Reaching fertilized oocytes to morula stage is in accordance with the results of Sultana et al (2009), who found that timing for the fertilized oocytes to be at morula stage was $32.5 \pm 0.7$ hours. In comparison with rabbit oocytes, Leibfried-Rytledge et al. (1987) obtained embryos at morulae and blastocysts after in vitro fertilization of in vivo mature bovine oocytes (recovered from oviduct). Oocytes that were matured in vitro and fertilized in vitro failed to develop to morulae in vivo.

Not all oocytes have the capacity to mature and to fertilize properly. Evidence has demonstrated that oocyte quality depends on the events that occur before GVBD (Blanco et al., 2011). The importance of oocyte quality, the second "intrinsic factor" in the developmental competence of embryos might be more apparent and is determined by the oocytes nuclear and cytoplasmic maturation which are attained during its growth in the follicle (Sirard, 2001). Generally, the number of pregnancies obtained under the same conditions is smaller when the transferred 
embryos are produced in vitro than when they are produced in vivo (Blanco et al., 2011).

Results shown in Table (3) revealed that percentage of embryos 4-cell stage significantly $(\mathrm{P}<0.05)$ decreased $(18.3$ vs. $34.7 \%)$ and at morula stage significantly $(\mathrm{P}<0.05)$ increased $(30.5$ vs. $16 \%)$ for in vivo as compared to in vitro matured oocytes. However, the differences in percentages of embryos at 2-cell and 8 16-cell stages between in vivo and in vitro matured oocytes were not significant.

Similarly with the present results, Kusan et al. (1984) found that $24 \%$ of oocytes progressed to normal 2-cell embryos in vitro. However when ovulated rabbit ova recovered from the ovarian surface were inseminated and fertilized in vitro, Brackett et al. (1971) found that $10 \%$ fertilized ova were in the 2-cell, $50 \%$ in the 4-cell and $10 \%$ in the 8 -cell stages after $24 \mathrm{~h}$ of insemination. Post in vitro fertilization of rabbit oocytes, Meshreky (1997) found that percentages of embryos at 1-cell, 2-cell, 4-cell and 8-cell stages in TCM-199 of control does were $2.6,9.5,7.8$ and $0.9 \%$ versus $1.7,10.5$, 9.4 and $2.8 \%$ in does treated with 75 IU PMSG (Foligon).

The observed difference in percentage of embryos at morula stage between in vitro and in vivo mature oocytes can be ascribed to the developmental potency of rabbit oocytes matured in culture remaining lower than that obtained in vivo.

Based on the foregoing results of this study, addition of $10 \%$ of bovine serum albumin (BSA) to tissue culture medium (TCM-199) had more beneficial effects on in vitro maturation rate of rabbit oocytes than that occurred with $10 \%$ of doe rabbit serum (DRS). In vitro maturation with $10 \%$ BSA showed success with satisfied in vitro fertilization rate and embryos at morula stage, but still to have lower developmental competence to fertilize in vitro than in vivo matured and in vitro fertilized oocytes.

\section{REFERENCES}

Abdoon, A.S.S., 2001. Factors affecting follicular population, oocyte yield and quality in camels (Camelus dromedarius) ovary with special reference to maturation time in vitro. Animal Reproduction Science, 66: 71-79.

Bavister, B.D., 1995. Culture of preimplantation embryos: facts and artifacts. Hum Reprod Update; 1:91-148.

Blanco, M.R, S., M. Demyda, Moreno Millán and E. Genero, 2011. Developmental competence of in vivo and in vitro matured oocytes: A review. Biotechnology and Molecular Biology Review, Vol. 6 (7): 155-165.
Brackett, B.G. and W.L. Williams,) 1965. In vitro fertilization of rabbit ova. J. Exp J. Zoot, 160:271-281

Brackett, B.G., D. Bousquet, M.A., Dressel,, 1982. In vitro sperm capacitation and in vitro fertilization with normal development in the rabbit .J.Androl., 3:402-411.

Brackett, B.G., D.E. Killen and M.D. Peace, 1971. Cleavage of rabbit ova inseminated in vitro after removal of follicular cell and zone pellucidae. Fertil .Steril.,22:816-828.

Carrell, D.T., L. Liu, I. Huang and M. Peterson, 2005. Comparison of maturation, meiotic competence, and chromosome aneuploidy of oocytes derived from two protocols for in vitro culture of mouse secondary follicles. J. Assist. Reprod. Gen., 22: 347-354.

Crozet, N., V. De Smedt, M. Ahmed-Ali and C. Sevellec, 1993. Normal development following in vitro oocytes maturation and fertilization in the goat. Theriogenology 39, 206.

Duncan, D.B., 1955. Multiple range and Multiple F test. Biometrics, 11:10.

El-Maghraby, E.F.A, 2004. Some factors affecting in vitro maturation of ovine oocytes M.SC Thesis Animal production Department, Ain Shams University.

Fahim, H.N., 2008. Some physiological and nutritional studies on rabbits. (ph.D)Thesis poultry production Department, Mansoura University.

Fukui, Y., T. Mogoe, H. Ishikawa, and S. Ohsumi, 1997. Factors affecting in vitro maturation of minke whale (Balaeno ptera acutorostrata) follicular oocytes. Bio. Reprod., 56.523-528.

Fukunari, A., M. Sasaba, T. Meada,, T. Terada, and Y. Tsutsumi, 1989. A mechanical and enzymatic approach to recovery of ovarian follicular oocyts in rabbits. Japanese $\mathrm{J}$. Anim. Reprod., 35:26-33.

Gifford, D. J., 1987. Protein synthesis in mature human oocytes. Gamete Res. 18: 97-107.

Hall, J.L. and B.G. BracKett, 1976. Enzymatic capacitation of ejaculated rabbit sperm in vitro. Presented at Society for Study of Reproduction Meeting. Philadelphia. Pa. Abs., 10: 20.

Holm, P., P.J. Booth, M.H. Schmidt, T. Greve and H. Callesen,, 1999. High bovine blastocyst development in a static in vitro production system using SOFaa medium supplemented with sodium citrate and myoinosotol with or without serum-proteins. Theriogenology, 52: 683-700.

Kane, M.T., 1985. A molecular weight extract of bovine serum albumin stimulates rabbit blastocyst cell division and expansion in vitro. J. Reprod. and Fertil., 73 : 147- 150. 
Kubelka, M., J. Motlik, J. Fulka, R. Prochazka, Z. Rimkevikova and J. Fulka, 1988. Time sequence of germinal vesicle breakdown in pig oocytes after cycloheximide and paminobenzamidine block. Gam. Res., 19: 423-431.

Kusan, F.B., A.D. Fleming and G.E. Seidel, 1984. Successful fertilization in vitro of fresh intact oocytes by previtelline (acrosome reacted) spermatozoa of the rabbit. Fertil. Steril., 41:766- 770.

Laurincik, J, D. Rath and H. Niemann, 1994. Differences in pronucleus formation and first cleavage following in vitro fertilization between pig oocytes matured in vivo and in vitro. Journal of Reproduction and Fertility 102, 277-284.

Leibfried-Rytledge, M.L., E.S. Critser; W.H. Eyestone, D.L. Northey and N.L. First, 1987. Development Potential of Bovine Oocytes Matured In Vitro or In Vivo. Biology of Reproduction 36, 376-383.

Martin-Lunas, M., A. Martino, M.T. Paramino, M.J. Palomo, M.T. Mogas, M.A. Bielsa, P. Andols and P. Martinez, 1996. Effect of oocytes sperm co incubation on acrosome reaction in the goat. Therigenology 46, 320-330.

Meshreky, S.Z.S., 1997. Some reproductive and producitve studies in rabbits. (ph.D), Animal production Department, Zagazig University.

Mills, J.A., G.G. Jeitles and B.G. Brackett, 1973. Embryo transfer following in vitro and in vivo fertilization of rabbit ova. Fertile. Steril., 24:602-608.

Minhas, B.S., W.E. Roudebush, D.D. Ricker and M.G. Dodson, 1991. Treatment of sperm with high-ionic strength medium increases microsurgical fertilization rates of in rabbit oocytes fertilized by subzonal placement of sperm. J. In vitro-Fertilization and Embryo Transfer, 8: 111-115.

Rajikin, M.H., M. Yusoff and R.B. Abdullah, 1994. Ultrastructural studies of developing goat oocytes in vitro. Theriogenology 42 , 1003-1016.
Rao, V.H. and N.K. Bhattacharyya, 1987. In vitro fertilization of rabbit ova. Current Science India. 56:787-788.

SAS, 2000. SAS Institute Inc. SAS User's Guide, Statistics. Cary, NC.

Sagirkaya, H., M. Yagmur, Z. Nur and M.K. Soylu, 2004. Replacement of fetal calf serum with synthetic serum substitute in the in vitro maturation medium: Effects on maturation, fertilization and subsequent development of cattle oocytes in vitro. Turk. J. Vet. Anim. Sci., 28:779-784.

Shamiah, Sh.M., 2004. Studies on in vitro fertilization in Egyptian buffaloes. Ph.D. Thesis, Faculty of Agriculture, Mansoura University, Egypt.

Shea, B.F., R.D. Bekar and J.P.A. Latour, 1976. Maturation in vitro of rabbit follicular oocytes .Candian.J. Anim.Sci. ,56:377-381.

Sirard, M.A., 2001. Resumption of meiosis: Mechanism involved in meiotic progression and its relation with developmental competence. Theriogenology, 55: 1241-1254.

Sirard, M.A. and P. Blondin, 1996. Oocyte maturation and IVF in cattle. Anim Reprod Sci;42:417-26.

Sirard, M.A., F. Richard, P. Blondin and C. Robert, 2006. Contribution of the oocyte to embryo quality. Theriogenology, 65: 126136.

Sultana, F., M. Hatori, N. Shimozaw, T. Ebisawa and T. Sankai, 2009. Continous observation of rabbit preimplantation embryo in vitro by using a culture device connected to a microscope. Journal of the Amercan Association Laboratory. Animal Science, 48(1): 52-56.

Tajik, P. and N. Shams Esfandabadi, 2003. In vitro maturation of Caprine oocytes in different culture media. Small Rumin. Res.47, 155-158.

Watson, A.J., 2007. Oocyte cytoplasmic maturation: A key mediator of oocyte and embryo developmental competence. J. Anim. Sci., 85 (13): E1-E3.

Table 1. Effect of supplementation of TCM-199 with different types of serum on in vitro maturation of oocytes

\begin{tabular}{|c|c|c|c|c|c|c|c|c|c|}
\hline \multirow{3}{*}{$\begin{array}{c}\text { Type of } \\
\text { TCM-199 }\end{array}$} & \multirow{3}{*}{$\begin{array}{c}\text { Number of } \\
\text { oocytes }\end{array}$} & \multicolumn{8}{|c|}{ Maturation stage } \\
\hline & & \multicolumn{2}{|c|}{ GV } & \multicolumn{2}{|c|}{ GVBD } & \multicolumn{2}{|c|}{ M I } & \multicolumn{2}{|c|}{ MII } \\
\hline & & $\mathbf{n}$ & $\%$ & n & $\%$ & $\mathbf{n}$ & $\%$ & $\mathbf{n}$ & $\%$ \\
\hline Control & 80 & 20 & 25.0 & 10 & 12.5 & 12 & $15.0^{b}$ & 38 & $47.5^{b}$ \\
\hline DRS & 80 & 10 & 12.5 & 6 & 7.5 & 20 & $25.0^{\mathrm{a}}$ & 44 & $55.0^{\mathrm{b}}$ \\
\hline BSA & 85 & 0 & 0.0 & 8 & 9.4 & 15 & $17.6^{\mathrm{ab}}$ & 62 & $73.0^{\mathrm{a}}$ \\
\hline
\end{tabular}

Control: without sera. $\quad$ DRS: Doe rabbit serum. $\quad$ BSA: Bovine serum albumin. $\quad$ GV: Germinal vesicles.

GVBD: Germinal vesicles breakdown. M I: Metaphase I. M II: Metaphase II. 
Table 2. In vitro fertilization rate $(\%)$ of in vivo and in vitro mature rabbit oocytes

\begin{tabular}{lcc}
\hline \multirow{2}{*}{ Item } & \multicolumn{2}{c}{ Mature oocytes } \\
\cline { 2 - 3 } & In vivo & In vitro \\
\hline Total recovered oocytes, $\mathrm{n}$ & 95 & 120 \\
Fertilized oocytes, $\mathrm{n}$ & 82 & 75 \\
Fertilization rate, $\%$ & $86.3^{\mathrm{a}}$ & $62.5^{\mathrm{b}}$ \\
Unfertilized oocytes*, $\mathrm{n}(\%)$ & $13(13.7)$ & $35(37.5)$ \\
\hline
\end{tabular}

${ }^{a}$ and $b_{\text {: }}$ Means denoted within the same row with different superscripts are significantly different at $\mathrm{P}<0.05$. * Number of unfertilized oocytes included immature and degenerated oocytes.

Table 3. Percentage of embryos at different stages after in vitro fertilization of in vivo and in vitro mature rabbit oocytes

\begin{tabular}{lcccc}
\hline \multirow{2}{*}{ Embryo stage } & \multicolumn{2}{c}{$\begin{array}{c}\text { In vivo mature } \\
\text { oocytes }(\boldsymbol{n = 8 2})\end{array}$} & \multicolumn{2}{c}{$\begin{array}{c}\text { In vitro mature } \\
\text { oocytes }(\boldsymbol{n}=\mathbf{7 5})\end{array}$} \\
\cline { 2 - 5 } & $\mathbf{n}$ & $\mathbf{\%}$ & $\mathbf{n}$ & \% \\
\hline 2-cell & 23 & 28.0 & 18 & 24.0 \\
4-cell & 15 & $18.3^{\mathrm{b}}$ & 26 & $34.7^{\mathrm{a}}$ \\
8-16 cell & 19 & 23.2 & 19 & 25.3 \\
Morula & 25 & $30.5^{\mathrm{a}}$ & 12 & $16.0^{\mathrm{b}}$ \\
\hline
\end{tabular}

${ }^{a}$ and $b^{b}$ : Means denoted within the same row with different superscripts are significantly different at $\mathrm{P}<0.05 . \mathrm{n}$ : Number of cleaved embryos.

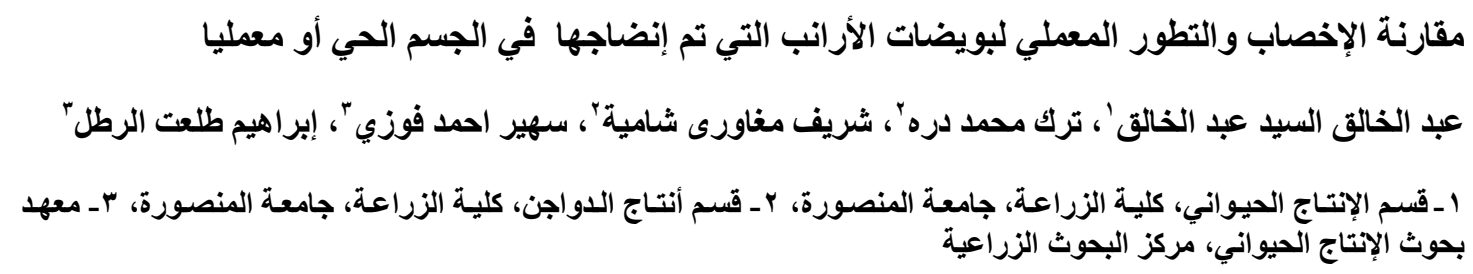

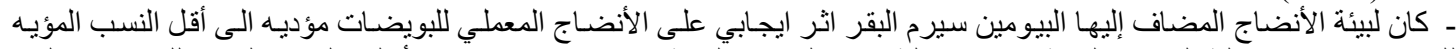

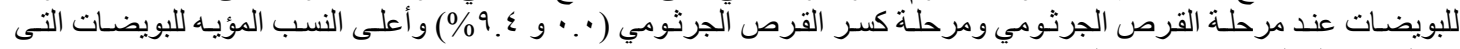

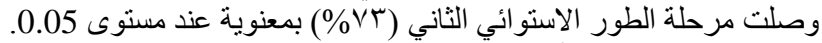
ـ كان معدل الإخصاب أعلى معنويا (عند مستوى 0.05) للبويضات المنضجة في الجسم الحي عن البويضات المنضجة معمليا (r.17

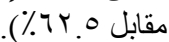

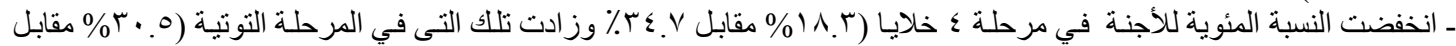

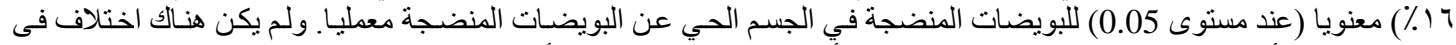

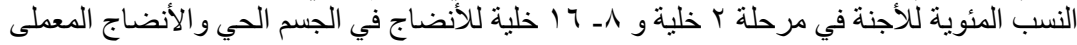

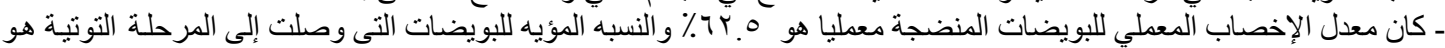

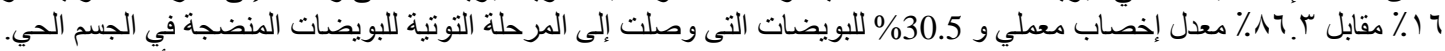

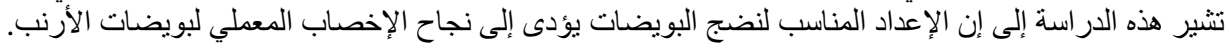

